THIS IS OUR COUNTRY, OUR WAY AND OUR HISTORY

I. M. ILINSKIY

MOSCOW UNIVERSITY FOR THE HUMANITIES

The text of the author's speech at the gala assembly dedicated to the 75 th anniversary of Moscow University for the Humanities. The event was held on December 5, 2019.

Keywords: Moscow University for the Humanities; anniversary; history of Russia; Komsomol; Higher Komsomol School; Central Komsomol School

Submission date: 05.12.2019.

Ильинский Игорь Михайлович - доктор философских наук, профессор, ректор Московского гуманитарного университета. Адрес: 111395, Россия, г. Москва, ул. Юности, д. 5. Тел.: +7 (499) 374-78-78. Эл. aspec: iilinskiy@mosgu.ru

Ilinskiy Igor Mikhailovich, Doctor of Philosophy, Professor, Rector, Moscow University for the Humanities. Postal address: 5, Yunosti St., Moscow, Russian Federation, 111395. Tel.: +7 (499) 374-78-78. E-mail: iilinskiy@mosgu.ru

DOI: $10.17805 /$ zpu.2019.4.2

\title{
МосГУ - 75: Время. События. Люди
}

\author{
А. Д. БОРОДАЙ \\ МОСКОВСКИЙ ГУМАНИТАРНЫЙ УНИВЕРСИТЕТ
}

Московский гуманитарный университет отмечает в 2019 г.славный юбилей - 75-летие со дня основания. Пройден большой путь в сфере высшего образования. Вуз за свою историю пять раз менял названия: Центральная комсомольская школа при ЦК ВЛКСМ (1944-1969) - Высшая комсомольская школа при ЦК ВЛКСМ(1969-1991) - Институт молодежи (1991-2000) - Московская гуманитарно-социальная академия (2000-2003) Московский гуманитарный университет (2003 - наст.).

Самое интересное, важное и ценное в истории нашего вуза - это люди. В университете всегда работали высококвалифицированные специалисты. Они имели большой опыт практической работы, стали известными учеными, создали свои научные школы. Преподаватели всегда были интересны студентам, потому что многое знали и многое умели. Главное, были щедрыми и интересными специалистами, уникальными личностями. В статье представлен ряд таких специалистов.

Ключевые слова: Высшая комсомольская школа; Московский гуманитарный университет; высшее образование; история университета

\section{ВВЕАЕНИЕ}

$\mathrm{B}$ далеком 1944 г., 11 октября, состоялось решение Оргбюро ЦК ВКП(б) «О Центральной комсомольской школе при ЦК ВАКСМ». На заседании Оргбюро выступили секретарь ЦК ВКП(б) Г. М. Маленков, заведующий отделом международной информации ЦК ВКП(б) А. С. Щербаков и первый секретарь ЦК ВАКСМ Н. А Михайлов. На этом заседании утвердили учебный план комсомольской школы. Рассмотрели план набора на 1944/1945 учебный год. Определили срок обучения - 1,5 года. Занятия предполагалось начать 15 декабря 1944 г. Требования к абитуриентам состояли 
в том, что это должны быть комсомольские работники и комсомольские активисты с полным средним образованием. Как вспоминали выпускники Центральной комсомольской школы (ЦКШ), первыми слушателями были комиссованные по ранению бойцы Красной армии, которые приехали в гимнастерках с орденами и медалями. Всего первый набор составил 260 человек. Из них участниками Великой Отечественной войны были 86 человек, т. е. каждый третий (Васильев, Мухамеджанов, 2011: 7)

В начале 1950-х гг. в ЦКШ при ЦК ВАКСМ училась большая группа слушателей из Китайской Народной Республики. Среди китайцев выделялся студент по имени Цянь Цичэнь. Спустя много лет он стал заместителем премьер-министра, министром иностранных дел КНР. В 2005 г. состоялся его официальный визит в Россию. В программе визита значилась встреча в Московском гуманитарном университете. На этой встрече с его помощью договорились о сотрудничестве МосГУ с Пекинским объединенным университетом. За последние 15 лет накоплен большой опыт взаимодействия двух вузов. В Зале Славы МосГУразмещен портрет нашего выпускника Цяня Цичэня (Ильинский, 2009: 47).

\section{НОВЫЙ СТАТУС КОМСОМОАБСКОЙ ШКОАЫ}

В 1969 г. Центральная комсомольская школа была преобразована в высшее учебное заведение, она стала называться Высшей комсомольской школой (ВКШ) при ЦК ВАКСМ. Было создано три факультета: факультет истории и коммунистического воспитания, факультет комсомольской работы и факультет зарубежных слушателей (факультет общественных наук). На первом из перечисленных факультетов обучались на базе среднего образования четыре года. Получали высшее образование и гражданскую специальность учителя истории. Прием на факультет комсомольской работы осуществлялся на базе высшего образования, слушатели учились два года. Это было второе высшее. На факультете зарубежных слушателей обучались иностранцы со всех континентов. Из общего контингента - 1600 человек половина была представлена зарубежными слушателями. Только переводчиков было более 130 человек, которые переводили на 28 языков.

Создание Высшей комсомольской школы при ЦК ВАКСМ происходило в соответствии с постановлением ЦК КПСС «О 50-летии ВАКСМ и задачах по коммунистическому воспитанию молодежи». Заведующих кафедрами, преподавателей Высшей комсомольской школы собирали по всей стране. Аля этого было принято специальное решение Моссовета о выделении 50 квот для прописки в Москве. Квартиры предоставлял ЦК ВАКСМ, и специальные жилые дома строили вблизи ВКШ при ЦК ВАКСМ. Тщательно подбирали ректора Высшей комсомольской школы при ЦК ВАКСМ. Его кандидатуру необходимо было согласовывать с ЦК КПСС. Выбор пал на Николая Владимировича Трущенко. Он был доктором исторических наук, профессором. Занимался научной проблематикой, связанной с историей комсомола. У Н. В. Трущенко был опыт работы заведующим отделом пропаганды Горьковского обкома КПСС. Затем он работал заведующим кафедрой истории КПСС в Горьковском университете. В пользу этой кандидатуры было его участие в Великой Отечественной войне. Николай Владимирович был награжден орденами и медалями. Имел ранения (Ильинский, 2009: 41).

Н. В. Трущенко остался в памяти его современников высоким, подтянутым и довольно шумным человеком. Одной из главных его особенностей была увлеченность идей создания комсомольского вуза. Он всего себя отдавал делу. Проработал Ни- 
колай Владимирович в должности ректора 17 лет, с 1969 по 1986 г. За это время Высшая комсомольская школа при ЦК ВАКСМ стала авторитетным вузом первой категории. Министерство высшего образования СССР с большим уважением относилось к комсомольскому вузу, активно помогало в его развитии. Важным было то, что с 1973 г. здесь была открыта аспирантура и началась подготовка аспирантов. Был создан диссертационный совет, на котором проходили защиты по истории КПСС и политической экономии. В дальнейшем появились новые научные специальности. За первые годы были построены два общежития на 1500 мест. В 1973 г. началось строительство 3-го учебного корпуса на 1000 мест, которое завершилось в 1982 г. (Ручкин, 2014: 9-11).

\section{ВСТРЕЧА С ВААЕРИЕМ АУКОВЫМ}

Первый человек, которого я встретил, приехав на учебу в ВКШ при ЦК ВАКСМ, был Валерий Андреевич Ауков. Он работал секретарем комитета комсомола, был выпускником факультета комсомольской работы 1972 г. Я зашел в комитет комсомола, потому что надо было передать привет Валерию Аукову от его однокурсника Виктора Бирка, который был направлен на работу в Хабаровский крайком комсомола. Виктор Бирк напутствовал меня и говорил, что надо использовать возможности Москвы, походить в театры, послушать хорошую музыку, побывать в музеях. Он говорил, что центр Москвы от Высшей комсомольской школы совсем недалеко. От станции метро «Ждановская» до «Площади Ногина» поезд идет 17 минут.

В дальнейшем Валерий Ауков перешел на работу в Научно-исследовательский центр. Через некоторое время защитил кандидатскую диссертацию. Затем стал доктором наук, известным в стране исследователем молодежи. Ему присвоено почетное звание «Заслуженный деятель науки Российской Федерации». А тогда мы были на их свадьбе с Натальей. Совсем недавно на даче $\Lambda$ уковых в Подмосковье отмечали сорокалетний юбилей их семьи. В гостях были давние друзья, которые участвовали в свадебном торжестве 40 лет назад.

Валерий Андреевич Ауков имеет огромный научный и творческий потенциал. Он вырос до директора научного центра, проректора по науке Московского гуманитарного университета. Но главное его призвание - исследователь. Он написал большое количество монографий и статей. Создал свое научное направление и научную школу. Вся жизнь ученого Валерия Андреевича Аукова связана с Московским гуманитарным университетом. В МосГУ он уже почти 50 лет (Валерий Андреевич $\Lambda$ ков ..., 2018).

«Эффект ботал его родной брат Владимир Андреевич Ауков (1948-2014). Владимир Андреевич Иуков был доктором филологических наук, прирожденным дитературоведом, знатоком отечественной и зарубежной литературы. Он работал проректором в Гуманитарном институте телевидения и радиовещания им. М. А. Аитовчина. Перешел на работу в МосГУ, но не сразу. Очень быстро стал известен в том числе и как энтузиаст $\Lambda$ итературной премии имени Ивана Бунина.

Из прошлого вспоминаю, как в 1976 г. Валерий и Владимир Иуковы создали студенческий театр и осуществили постановку спектакля. Это было событие. После премьеры слушатели делились своими впечатлениями от спектакля и творческой работы в театральной студии. Помню, как слушательница четвертого курса Наталья Керестеджиянц сказала: «Радость Вы наша Ауковая! Какое счастье доставили всем, кто играл 
и кто смотрел спектакль. Спасибо вам!» Это был тоже «эффект $\Lambda$ ковых». Они создали нечто необыкновенное в коллективе. Талантливыми оказались не только режиссеры, но и самодеятельные актеры.

\section{НАШ АОЗУНГ: «СКОРЕЙ БЫ УТРО, АА НА РАБОТУ»}

Я приехал на учебу в ВКШ при ЦК ВАКСМ из Хабаровска 31 августа 1973 г. Анем раньше все мои однокурсники, с которыми мы познакомились и успели подружиться на вступительных экзаменах, уехали на уборку урожая в Каширский совхоз в Подмосковье. Мне очень хотелось поехать к своей группе. Я об этом просил декана К. Ц. Петросяна и Валерия Аукова. Наконец приехал первый заболевший студент, и я вместо него на электричке поехал искать своих однокурсников в Каширу.

За дни, проведенные на полях Каширского совхоза, мы сплотились и получили опыт коллективного труда, стали еще больше ценить чувство юмора. Это было связано вот с чем. Неделя тяжелого и интенсивного труда породила усталость. Некоторым однокурсникам казалось, что кто-то работает меньше других. Чтобы снять подозрения, староста группы Слава Королев (он был из Аипецка) предложил вечером собраться в большой комнате, выключить свет и поговорить в темноте начистоту. Так и сделали. В полной темноте по кругу стали говорить, что «надо брать больше и кидать далыше». Мы копали и вывозили с полей картофель, капусту и другие овощи. Высказались несколько человек. Очередь дошла до Алексея Ковальчука. Он был с Украины, из города Ровно. Алексей вроде как задремал и молчал. Председательствующий сказал: «Алексей, а ты что думаешь?» В ответ последовала следующая фраза: «Что я думаю? Я думаю, скорей бы утро, да на работу». Эта фраза вызвала смех. Все оценили украинский юмор. На этом собрание закончилось. Все согласились, что «скорей бы утро, да на работу».

В конце сентября вернулись в Москву на учебу. Состоялось организационное собрание слушателей первого курса.

\section{ПЕРВЫЙ РЕКТОР КОМСОМОАЬСКОГО ВУЗА}

Сильное впечатление было от знакомства с ректором Высшей комсомольской школы при ЦК ВАКСМ доктором исторических наук, профессором Николаем Владимировичем Трущенко. Он встречал нас как новое поколение слушателей, выступил с яркой, зажигательной речью. Призывал не только учиться, но и на практике решать задачи, которые стоят перед комсомолом. Нашей группе Б12 он предложил сформировать идеологический отряд и внедрять новые формы работы с молодежью.

После окончания ВКШ я работал в Высшей комсомольской школе при ЦК ВАКСМ вместе с Николаем Владимировичем Трущенко с 1975 по 1986 г. Участвовал в заседаниях ректората, совещаниях, приемной комиссии. Главное впечатление тех лет - это неутомимая энергия ректора по созданию комсомольского вуза. Надо было заложить лучшие традиции высшего образования, обеспечить государственный подход к подготовке кадров для страны. Во все, что касается учебной деятельности, Николай Владимирович вникал лично и многое делал сам. Он заведовал кафедрой, читал курс лекций, вел семинарские занятия в одной из групп на факультете истории и коммунистического воспитания. Это давало ему возможность определять профессиональную планку для остальных преподавателей, знать потенциал слушателей. Его опыт работы в Горьковском университете был для әтих целей очень важным (Наш страж..., 1999: 51-57). 
В Москву из Горького Николай Владимирович «перетянул» двух высококвалифицированных специалистов. Особой симпатией в коллективе пользовалась Валерия Евгеньевна Ярнатовская. Она была доктором филологических наук, профессором, долгие годы возглавляла кафедру иностранных языков.

Среди земляков Николая Владимировича был проректор по научной работе Владимир Алексеевич Смирнов. Затем он перешел в Научно-исследовательский центр. При активной поддержке ЦК комсомола он собирал со всей страны специалистов высшей квалификации по общественным наукам и молодежному движению.

Из Ставрополя приехал доктор исторических наук, профессор Александр СоломоновичТрайнин, из Свердловска - доктор экономических наук, профессор Анатолий Васильевич Моисеев, из Красноярска - доктор философских наук, профессор Владимир Николаевич Аавриненко, из Чебоксар - доктор экономических наук, профессор Виталий Николаевич Якимов, из Новочеркасска - доктор философских наук, профессор Алексей Васильевич Мялкин, из Орла - доктор исторических наук, профессор Михаил Иссидорович Шилобод, из Ростова-на-Аону - доктор филологических наук, профессор Тамара Александровна Хмелевская и доктор философских наук, профессор Виталий Васильевич Журавлев. Из Москвы пригласили доктора исторических наук, профессора Юрия Степановича Борисова, доктора юридических наук, профессора Таира Фаридовича Таирова и доктора исторических наук, профессора Владлена Георгиевича Сироткина. Подготовка своих собственных докторов проходила позднее, так как в то время в Москве защищать докторскую диссертацию в возрасте до 50 лет не было принято.

Важнейшим элементом стратегии становления и развития вуза Николай Владимирович считал создание диссертационных советов. Первый совет возник в 1970 г. В диссертационных советах ВКШ (МосГУ) защищались граждане 30 государств. Система диссертационных советов получила свое развитие. В 2010 г., например, в Московском гуманитарном университете (правопреемнике ВКШ при ЦК ВАКСМ) работали семь диссертационных докторских советов по 17 специальностям. За прошедшие почти 50 лет со дня основания первого совета защитились более 1300 соискателей.

Наряду с подбором кадров Николай Владимирович активно занимался развитием материальной базы. Началось проектирование учебного корпуса на 1000 мест и двух корпусов современных общежитий. Общежития корпусов «Г» иА» каждый в девять этажей и по 640 мест были суперсовременными. Ааже сегодня, спустя 40 лет, мало какой столичный вуз располагает такими студенческими комплексами. Их построили очень быстро и ввели в эксплуатацию один в 1972 г., другой - в 1974 г. Эти объекты строили подразделения «Главмосстроя» по категории «жилые помещения», был жесткий контроль со стороны партийных и хозяйственных органов (Ручкин, 2014:11).

\section{ПОРУЧЕНИЕ ПЕРВОГО СЕКРЕТАРЯ ЦК ВАКСМ}

В июне 1975 г. завершалось мое обучение в Высшей комсомольской школе при ЦК $\mathrm{B} \Lambda \mathrm{KCM}$, и я должен был возвратиться на Аальний Восток. Меня ждали в Хабаровском крайкоме комсомола, чтобы предложить какой-либо участок работы. Возможностей было более чем достаточно. Но за два месяца до окончания произошли события, которые изменили не просто планы, но и дальнейшую судьбу.

Секретарь комитета комсомола Вячеслав Коновалов, с которым мы одновременно заканчивали учебу, решил возвращаться в Красноярский край. Этот вопрос был решен на уровне первого секретаря Красноярского крайкома партии, поэтому альтернатив 
здесь уже не было. Меня пригласил к себе секретарь парткома Виктор Федорович Ауванов и предложил остаться в ВКШ на должности секретаря комитета комсомола. Понятно, что эта позиция была согласована с ЦК В ККСМ. По процедуре такое решение было наиболее простым. На заседании комитета комсомола надо было проголосовать - и все. Аалее, осенью проводить отчетно-выборное собрание и избираться в состав комитета ВАКСМ вместе с другими выдвигаемыми кандидатурами.

В конце апреля состоялось заседание комитета комсомола, на котором меня избрали секретарем. Затем предстояло пройти утверждение в должности на Секретариате ЦК ВАКСМ. 20 мая 1975 г. меня пригласили на заседание Секретариата ЦК ВАКСМ, которое вел Е. М. Тяжельников. Оно проходило в зале заседаний ЦК ВАКСМ на четвертом этаже. Присутствовали из ВКШ при ЦК ВАКСМ ректор Н. В. Трущенко и секретарь парткома В. Ф. Ауванов.

По кадровым вопросам докладывал заведующий отделом комсомольских организаций В. Т. Иванов. Он огласил мои анкетные данные. Е. М. Тяжельников спросил: «Товарищи, какие будут вопросы, мнения?» Первый секретарь Московского горкома комсомола В. М. Мишин задал вопрос: «А достаточно ли у Александра опыта, чтобы возглавлять такую организацию?» Е. М. Тяжельников в ответ высказал такое мнение: «В чем задача секретаря комитета комсомола ВКШ на данном этапе? Организовать интересную жизнь и деятельность комсомольской организации. Посмотрите, он окончил институт культуры, проявил себя как инициативный организатор. Я думаю, что новому секретарю комитета комсомола нашего комсомольского вуза надо поручить создать хорошую самодеятельность и выступить перед работниками аппарата ЦК ВАКСМ с концертом. Есть предложение утвердить кандидатуру Бородая Александра в должности секретаря комитета комсомола ВКШ при ЦК ВАКСМ».

Я с облегчением выдохнул и вышел из зала. Начались напряженные дни. Надо было готовиться к выпускным экзаменам и одновременно организовывать работу комитета комсомола.

Прошла примерно неделя. Меня приглашает Николай Владимирович Трущенко и спрашивает: «Саша, ты понял, что на заседании Секретариата ЦК ВАКСМ тебе первый секретарь дал очень серьезное поручение? Как ты его собираешься выполнять?» Вопрос для меня был неожиданным. Я стал перебирать в памяти прозвучавшее на заседании, чтобы определить, каким было поручение. Николай Владимирович продолжил: «Ты имей в виду, что у Евгения Михайловича очень хорошая память. Он не забудет того, что тебе сказал, вернется к вопросу о художественной самодеятельности и выступлении с концертом в ЦК ВАКСМ. Что ты собираешься делать?»

Признаюсь, что я не оценил конкретность данного поручения. Однако экспромтом стал рассуждать о реальной возможности подготовить программу и выступить с концертом. Я сказал Николаю Владимировичу: «У нас есть слушатели, которые владеют музыкальными инструментами, хорошо поют. Но мы не можем создать вокально-инструментальный ансамбль, потому что нет аппаратуры». Он спросил: «Какая аппаратура нужна?» Ответ у меня был готов, поскольку этот вопрос мы обсуждали в комитете комсомола. Я сказал, что желательно приобрести комплект аппаратуры «BIAG» венгерского производства. Николай Владимирович тут же набрал телефон управляющего делами ЦК ВАКСМ Владимира Михайловича Ситцева и задал ему вопрос о возможности приобрести такую аппаратуру для Высшей комсомольской школы. В. М. Ситцев ответил, что этот вопрос сложный. Госплан выделяет ЦК ВАКСМ только два комплекта в год, а заявок только от ударных комсомольских 
строек в Управлении делами находится более десятка. Н. В. Трущенко в ответ сказал: «У вас ведь комсомольский вуз один. Тем более что первый секретарь дал специальное поручение комитету комсомола ВКШ». Было ясно, что этот вопрос быстро решен быть не может. Николай Владимирович по местному телефону позвонил секретарю парткома В. Ф. Ауванову и попросил его зайти. Через минуту в кабинет вошел секретарь парткома. Ректор кратко проинформировал его о вопросе, который обсуждается.

Виктор Федорович Ауванов включился в обсуждение проблемы. Обратил внимание, что в комсомольском вузе учится группа молодежных лидеров из Венгрии. Существовала практика приглашения в ВКШ послов различных стран для укрепления сотрудничества. Ректор попросил секретаря приемной пригласить к нему проректора по работе с зарубежными слушателями Кима Алексеевича Юстеньянца. Все вместе договорились пригласить с визитом в Высшую комсомольскую школу посла Венгерской Народной Республики в Москве. Поводом предстоящей встречи было успешное окончание учебы группы слушателей из Венгрии.

В начале июня посол Венгерской Народной Республики приехал с визитом в Высшую комсомольскую школу при ЦК ВАКСМ. Состоялась встреча в актовом зале с советскими слушателями и представителями зарубежных стран. Посол сделал доклад о социально-экономическом развитии Венгрии и политической жизни страны. После этого собрались в кабинете ректора, где продолжили разговор в непринужденной обстановке. Здесь ректор высказал просьбу помочь приобрести аппаратуру венгерского производства компании «BIAG». Посол ответил: «Мы подумаем над этим вопросом». В итоге к началу нового учебного года посольство Венгрии подарило Высшей комсомольской школе комплект аппаратуры.

Концерт в зале ЦК ВАКСМ состоялся в день рождения комсомола 29 октября. Руководил ансамблем Геннадий Урмаев, который приехал из Татарстана и учился на факультете комсомольской работы. Программа была интересной и по качеству соответствующей. Зрителям понравилось исполнение песни «Ионел» слушательницы из Молдавии Аюдмилы Гуцу и романсы в исполнении Валентина Прудкого из Украины. Ансамбль спел песню Георгия Мовсесяна на стихи $\Lambda$ ьва Ошанина «Мне доверена песня». Осталась фотография, на которой ректор Н. В. Трущенко и секретарь парткома В. П. Мошняга слушают концерт, сидя в последнем ряду зала заседаний ЦК ВАКСМ. По факту конкретное поручение первого секретаря ЦК В $\Lambda$ КС было выполнено.

\section{ВЫСТУПАЕНИЕ Б. Н. ЕАЬЦИНА}

Из памятных событий, которые проходили в комсомольском вузе, следует назвать встречу с Борисом Николаевичем Ельциным, которая состоялась 12 ноября 1988 г. К этому времени он был освобожден как кандидат из состава Политбюро ЦК КПСС, снят с должности первого секретаря МГК КПСС. В то же самое время оставался членом ЦК КПСС и работал в Госстрое СССР в ранге министра. Полным ходом шла так называемая перестройка. М. С. Горбачев призывал расширять гласность. ОАин из студентов, который приехал учиться из Свердловской области и был земляком Б. Н. Ельцина, проявил инициативу, чтобы пригласить его на встречу со слушателями. Это был Юрий Раптанов. Надо заметить, что все слушатели были членами КПСС и имели, по их мнению, право получить информацию из первых уст. Партком ВКШ при ЦК ВАКСМ и его секретарь В.С. Коновалов заняли позицию, согласно кото- 
рой молодые коммунисты имеют право встретиться с Б. Н. Ельциным. Было очень сильное давление из МГК КПСС, Перовского райкома партии на партком, чтобы эту встречу не допустить. Но она все-таки состоялась и вызвала большой интерес. У меня сложилось впечатление, что для Б. Н. Ельцина это был старт на президентскую дистанцию.

В книге «Исповедь на заданную тему» Б. Н. Ельцин (Ельцин, 1992) на двух страницах рассказывает о встрече в Высшей комсомольской школе. В этом сюжете использован диалог с М. С. Горбачевым в перерыве на Пленуме ЦК КПСС (там же: 37-37). Читателям книги этим передан сигнал о ее значении. Она стала предметом обсуждения с руководителем страны. Итог ноябрьской встречи автор оценил так: «И все-таки, я чувствовал, лед тронулся. Мое заточение подходит к концу. Начинается какоето новое время, совершенно неизведанное, непривычное. И в этом времени пора находить себя (там же: 37).

Как известно из последующих событий, 26 марта 1989 г. на состоявшихся альтернативных выборах народных депутатов СССР по Московскому национально-территориальному округу № 1 избиратели отдали $89,6 \%$ голосов за Б. Н. Ельцина. Этим закончился марафон, который стартовал для будущего президента России 12 ноября 1988 г. в Высшей комсомольской школе. Б. Н. Ельцин стал народным депутатом, а затем и Председателем Верховного Совета РСФСР. Через два года он стал Президентом России.

Необходимо подчеркнуть, что Б. Н. Ельцин на встрече был максимально корректным. За четыре часа выступления и ответов на вопросы он не допустил ни одного резкого высказывания против кого-либо из своих бывших коллег. При этом отстаивал свою собственную точку зрения на многие вопросы жизни страны.

Встреча проходила в актовом зале 3-го учебного корпуса. Она началась в 16 часов и закончилась в 20 часов 20 минут. Из зала в президиум передали более 300 вопросов. На 75 из них были даны ответы. Многие вопросы повторялись. Поэтому В. С. Коновалов, находясь в президиуме, их объединял и передавал Б. Н. Ельцину.

Интересно представить участвующих в этой встрече людей. Актовый зал на 800 мест не вместил всех желающих. Были советские слушатели, преподаватели, руководители молодежных газет и журналов, которые в это время проходили повышение квалификации в ВКШ при ЦК ВАКСМ. Один ряд попросили для представителей спецслужб и районных партийных органов. Был в зале известный историк Рой Медведев, который в этот день выступал перед редакторами молодежных изданий.

Атмосфера встречи была раскрепощенная. Вопросы задавали в микрофон и писали записки. Если бы в зале кто-либо остался не удовлетворен тем, что на его вопрос не ответили, то возможность повторить его была неограниченная. Б. Н. Ельцин общался с залом, стоя за трибуной. Он подчеркивал этим, что обладает хорошим здоровьем. В начале встречи предложил «работать до упора». Встречу решили закончить по инициативе одной из сторон.

На Пленуме МГК КПСС 11 ноября 1987 г. в заключительном слове Б. Н. Ельцин говорил: «Я честное партийное слово даю, никаких умыслов я не имел, и политической направленности в моем выступлении не было... Я потерял как коммунист политическое лицо руководителя. Я очень виновен перед Московской партийной организацией, очень виновен перед горкомом партии»1.

По этому поводу на встрече был задан следующий вопрос: «Почему на Пленуме Московского горкома партии Вы согласились практически со всеми замечаниями чле- 
нов пленума? Означает ли это, что Вы действительно согласились, или эта стенограмма была неполной?» Ответ Б. Н. Ельцина был следующим: «Стенограмма была несколько искажена. В то время я был тяжело болен и прикован к постели. Мне было приказано через полтора часа быть на Пленуме. Что в меня вливали, я не знаю до сих пор. Откровенно говоря, я был просто отключен. Разве я бы допустил такую ложь и клевету в свой адрес. Я бы резко бросался в атаку, не дожидаясь финала. Как я пошел? Подкорку они отключили ${ }^{2}$.

Б. Н. Ельцину был задан вопрос: «В Вашей речи на Пленуме ЦК, в том варианте, который “ходил” по Москве, упоминалось имя Раисы Максимовны Горбачевой...» По этому поводу Б. Н. Ельцин построил ответ очень интересно. Он сказал: «Первое. Я знаю о наличии трех вариантов моего выступления, которые ходили по Москве, даже продавались у станций метро. Во всех трех вариантах упоминалось, будто бы я говорил о Раисе Максимовне Горбачевой. Я даю слово и считаю, что для выступления члена ЦК на Пленуме это просто несерьезно. Я такой вопрос не поднимал, о нем не говорил на Пленуме» ${ }^{3}$.

В этом месте он сделал паузу и как бы нехотя продолжил: «Аругое дело, какого я мнения...» (в зале раздаются аплодисменты). Возгласы из зала: «Какого мнения?» Б. Н. Ельцин: «Я считаю так. Что касается международных дел, то существует международный протокол. И здесь нет вопросов. А что касается внутри страны - я бы этого не делал» (аплодисменты) ${ }^{4}$.

Из 75 полученных ответов мы попытаемся выделить несколько вопросов по уровню интереса аудитории. На первое место, по нашему мнению, претендуют вопросы, связанные с содержанием речи Б. Н. Ельцина на Октябрьском (1987 г.) Пленуме ЦК КПСС. Смысл ответа на них выражен фразой «Вы меня ставите в положение очень трудное».

На второе место следует отнести вопрос о том, была ли договоренность с М. С. Горбачевым не выступать на Пленуме ЦК КПСС. Реакция на этот вопрос была следующей: «Л понимаю, что сегодняшний текст ляжет ему на стол» (аплодисменты).

Следующий интересный вопрос звучал так: «Борис Николаевич! Ваша популярность не меньше, чем у Михаила Сергеевича Горбачева. Могли бы Вы возглавить партию и государство?» (взрыв аплодисментов). Б. Н. Ельцин: «Когда будут альтернативные кандидатуры - могу поучаствовать» (аплодисменты). Б. Н. Ельцин был интересен аудитории. Его ответы были живыми, искренними и разумными. Позиция подкупала: он демонстрировал борьбу за справедливость. Он был уверен в себе.

Техническая оснащенность ВКШ при ЦК ВАКСМ позволяла сделать видеосъемку встречи, вести аудиозапись, фотографировать. Видеозапись была изъята в этот же вечер для просмотра и анализа в компетентных органах. На самой встрече присутствовали 40 человек из партийного аппарата и специальных служб. Аублирующая аудиозапись на четырех кассетах была сохранена автором данной статьи.

\section{КААРЫ - ГААВНЫЙ ВОПРОС}

В книге «Беседы об истории Московского гуманитарного университета» ректор университета доктор философских наук, профессор И. М. Ильинский вспоминал один интересный эпизод. В конце 1960-х годов он работал первым заместителем заведующего Отделом комсомольских органов ЦК ВАКСМ и занимался созданием Высшей комсомольской школы. В его компетенцию входил подбор кадров для комсомольского вуза. Это была не простая задача. При том, что в известном постановлении 
ЦК КПСС было предусмотрено выделение квоты на 50 человек для перевода специалистов высшей квалификации из любого региона в столицу. Среди подобранных специалистов был доктор исторических наук, профессор А. С. Трайнин.

Вот как об этом вспоминает Игорь Михайлович: «Александр Соломонович Трайнин, которого мы не без труда перетащили из Ставропольского госуниверситета, на мой взгляд, являл собой образец профессора советского периода. Тому, как относился к делу, у него можно было бы поучиться очень многим и сегодня. Он очень глубоко знал предмет, который преподавал. Мимо него не могла проскочить ни одна кандидатская и уж тем более докторская диссертация по истории партии и комсомола. Он исписывал замечаниями целые школьные тетрадки. Студенты и аспиранты его любили, потому что он любил их, по-настоящему с ними работал. Мы жили в одном доме на 2-й Новоостанкинской улице, 19, я - на девятом, а он - на третьем этаже. Я иногда заходил к нему. Всегда у него был кто-то из студентов или аспирантов. Это был Учитель» (Ильинский, 2009: 56).

В архиве семьи Трайниных сохранилось письмо, подготовленное ректором Высшей комсомольской школы при ЦК ВАКСМ доктором исторических наук, профессором Н. В. Трущенко, в адрес ректора Ставропольского государственного педагогического института доцента А. П. Чевелева. Оно зарегистрировано 11 сентября 1969 г. Содержание следующее: «Ректорат Высшей комсомольской школы при ЦК В ККСМ просит Вас согласно договоренности ЦК В $\Lambda$ КСМ с Ставропольским краевым комитетом КПСС освободить профессора кафедры истории КПСС тов. Трайнина А. С. в порядке перевода в ВКШ при ЦК В $\Lambda$ КСМ».

Профессор А.С. Трайнин был одним из создателей научной школы по истории юношеского и молодежного движения, становления и развития комсомола, которая формировалась в Высшей комсомольской школе при ЦК ВАКСМ в 1970-1980-е гг. За четверть века работы в Высшей комсомольской школе и Институте молодежи, с 1969 по 1994 г., Александр Соломонович Трайнин подготовил 17 аспирантов. В их числе была аспирантка из Кубы Мерседес де Армас Алонсо. Она защитила в 1986 г. кандидатскую диссертацию на тему «Использование исторического опыта КПСС в деятельности коммунистической партии Кубы по организации и воспитанию учащейся молодежи (1959-1975 гг.)». Ава человека из числа его аспирантов - Сергей Усов и Семенов в дальнейшем стали докторами исторических наук. В Педагогическом институте г. Ставрополя было подготовлено еще девять аспирантов. Таким образом, за свою педагогическую практику путевку в науку Александр Соломонович дал 26 своим подопечным.

\section{ПОКОРЕНИЕ СИБИРИ}

В середине 1970-х гг. началось движение выпускников Высшей комсомольской школы по покорению Сибири. Несколько десятков человек распределялись в Красноярский край на работу. Этому порыву способствовали определенные обстоятельства. В 1975 г. в Красноярский край попросил распределение выпускник ВКШ Вячеслав Коновалов. Он стал работать заведующим организационным отделом Красноярского крайкома В $\Lambda$ КСМ. В свое время он приехал на учебу в Высшую комсомольскую школу с должности заведующего организационным отделом Норильского горкома комсомола. Хотя родился в Рыбинске Ярославской области, но считал себя красноярцем. Поэтому поехал в Красноярск после окончания учебы в ВКШ при ЦК ВАКСМ. По должностным обязанностям он отвечал за кадры. Как выпускник, имел связи с фа- 
культетом истории и коммунистического воспитания Высшей комсомольской школы и принимал на работу выпускников этого факультета.

Одним из первых в Красноярский край поехал Владимир Перепелица. Он служил в Кремлевском полку. Занимался комсомольской работой. После службы был направлен на учебу в Высшую комсомольскую школу при ЦК ВАКСМ. Работал с Вячеславом Коноваловым в комитете комсомола. Занимался интернациональной работой. Родом был из Харьковской области. В 1976 г. Владимир Перепелица получил распределение в Красноярск. Работал там несколько лет. Был вторым секретарем Красноярского горкома комсомола. В Красноярском крайкоме комсомола работали Богдан Хаврун (заведующий отделом студенческой молодежи), Тамара Илькевич (заведующая отделом агитации и пропаганды), Валентина Иванова (секретарь крайкома комсомола по работе с учащейся молодежью), в крайкоме комсомола работали Вера Оськина (впоследствии депутат ГА РФ) и другие. Всего в Красноярский край было направлено более 40 человек.

Такое отношение к Красноярскому краю было продиктовано еще одним обстоятельством. В 1971 г. из Академии общественных наук при ЦК КПСС в Высшую комсомольскую школу распределили Юрия Николаевича Афанасьева. Ранее он был секретарем Красноярского крайкома ВАКСМ по работе с учащейся молодежью. Получил приглашение на работу в Центральный совет Всесоюзной пионерской организации, где несколько лет был заместителем председателя этой организации. После окончания комсомольской работы был рекомендован на учебу в Академии общественных наук при ЦК КПСС. В Высшей комсомольской школе его избрали секретарем парткома. В этой должности он проработал один год и был утвержден проректором ВКШ при ЦК ВАКСМ по учебной работе.

Как человек красноярского происхождения, имеющий связи с этим регионом, лично знавшим первого секретаря Красноярского крайкома партии, Ю. Н. Афанасьев участвовал в решении вопросов распределения выпускников в Красноярский край, направления туда студенческих строительных отрядов ВКШ. Один из его приятелей работал в Красноярске руководителем крупного строительного треста. Он с большим удовольствием принимал студенческий строительный отряд будущих комсомольских работников на разные строительные площадки края. Несколько лет слушатели ездили строить Надеждинский металлургический завод под Норильском. Работа в студенческих строительных отрядах в Красноярском крае, знакомство с центральным регионом Сибири способствовали распределению в Красноярский край выпускников Высшей комсомольской школы при ЦК ВАКСМ.

Будучи проректором по учебной работе, Ю. Н. Афанасьев курировал оснащение строившегося учебного корпуса № 3 техническими средствами обучения. Перед ним была поставлена задача построить самый современный учебный корпус. Прежде всего необходимо было оборудовать аудитории учебным телевидением. Такие аудитории стали предвестниками мультимедийных лекционных залов. Из единого центра в учебную аудиторию могли передать учебный фильм, показать слайды и т. А. Одновременно Ю. Н. Афанасьев работал над докторской диссертацией. Она была связана с историей Франции. Ава года он был на должности старшего научного сотрудника, чтобы завершить диссертационное исследование. В итоге докторская диссертация была защищена.

В 1982 г. Юрий Николаевич Афанасьев перешел на работу в журнал «Коммунист». В период перестройки и роспуска СССР был одним из создателей Межрегиональной 
депутатской группы. Затем его утвердили ректором Московского историко-архивного института. На его базе он создал Российский государственный гуманитарный университет. Благодаря связям с мәром Москвы Г. Х. Поповым в распоряжение РГГУ перешел учебный комплекс зданий, ранее принадлежавший Высшей партийной школе при ЦК КПСС.

В 1989 г. Ю.Н. Афанасьев баллотировался и был избран депутатом Верховного Совета СССР. Первое собрание по выдвижению его кандидатом в депутаты проходило в Высшей комсомольской школе. Рассматривались несколько кандидатур: Ю. Н. Афанасьев, В. С. Коновалов, К. П. Скопина. При голосовании Ю. Н. Афанасьев получил большинство голосов. Партийные органы Москвы, Перовский райком партии не поддерживали кандидатуру Ю. Н. Афанасьева, всячески препятствовали его избранию кандидатом в депутаты. Требовали отозвать протокол собрания. В итоге избирательная комиссия признала его недействительным. После этого Ю. Н. Афанасьева выдвинули кандидатом в депутаты по Ногинскому избирательному округу в Московской области. Так он стал депутатом Верховного Совета СССР.

В опубликованной биографии Ю. Н. Афанасьева не освещается его работа в Высшей комсомольской школе, где он трудился с 1971 по 1982 г. В этот период он получил опыт управления высшим учебным заведением, защитил докторскую диссертацию. Это способствовало выбору его дальнейшего трудового пути, когда он перешел на работу в Московский историко-архивный институт и преобразовывал его в Российский государственный гуманитарный университет.

\section{ВЫПУСКНИКИ ВКШ НА БАМЕ}

Как известно, в 1974 г. началось строительство Байкало-Амурской магистрали. Стратегическая задача состояла в том, чтобы проложить путь к новым месторождениям полезных ископаемых и выйти к Тихому океану севернее Транссибирской железнодорожной магистрали. В этом решении был еще и военно-стратегический аспект. Транссибирская железнодорожная магистраль на Аальнем Востоке проходит в 100 км от советско-китайской границы. При отношениях, которые складывались с Поднебесной в период китайской культурной революции, это было небезопасно.

Строительство Байкало-Амурской железнодорожной магистрали было объявлено Всесоюзной ударной комсомольской стройкой. Задача Высшей комсомольской школы при ЦК ВАКСМ состояла в том, чтобы обеспечить кадрами комсомольские организации в зоне строительства БАМа. Первые представители ВКШ при ЦК ВАКСМ поехали на Аальний Восток в 1975 г. В столицу БАМа - город Тынду направили выпускников, которые получили дипломы с отличием. Это были Татьяна Попова, Владимир Аавриненко, Виктор Орлов и Владимир Климченко. Татьяна Попова работала в штабе ЦК В $\Lambda$ КС, затем была переведена в Амурский обком комсомола. Владимир Аавриненко начинал работать секретарем комитета комсомола главка «Бамстроймеханизация». Через некоторое время его избрали вторым секретарем Тындинского горкома комсомола. Виктор Орлов возглавил комитет комсомола треста «Бамстройпуть». Владимир Климченко работал секретарем комитета комсомола треста «остоотряд».

В 1976 г. на БАМ направили выпускника факультета истории и коммунистического воспитания Виктора Муконина. В итоге он стал первым секретарем Тындинского горкома комсомола. Проработал в Тынде несколько лет. Вернулся в аспиран- 
туру Высшей комсомольской школы. Спустя три года успешно защитил диссертацию. Работал начальником учебно-методического отдела Института молодежи. Затем перешел на работу в сферу банковской деятельности (Благодаря комсомолу..., 2018: 181-186).

На одном из заседаний Русского интеллектуального клуба, который действует в Московском гуманитарном университете, в 2018 г. Виктор Муконин говорил о том, что выпускники ВКШ при ЦК ВАКСМ были направлены на работу в зону строительства Байкало-Амурской магистрали: Бурятский обком В $\Lambda \mathrm{KCM}$, Читинский обком ВАКСМ, Амурский обком ВАКСМ, обком ВАКСМ ЕАО, Хабаровский крайком ВАКСМ. Многие из выпускников продолжают работать на Аальнем Востоке. Аругие вернулись на малую родину, в разные регионы России (там же: 183).

\section{ЗАКАЮЧЕНИЕ}

$\Lambda$ юди, о которых рассказано в статье, были связаны с нашим вузом многие годы. Часть из них посвятили свою жизнь подготовке кадров для самой большой и авторитетной молодежной организации, которая называется Всесоюзный Аенинский Коммунистический Союз Молодежи. Трудно посчитать количество выпускников МосГУ за 75 лет его существования. Это будет несколько десятков тысяч. Только в период с 1971 по 1991 г. наш вуз, по некоторым данным, окончили более 20 тыс. выпускников. За последние 30 лет еще примерно 25-30 тыс. Среди наших выпускников есть члены Правительства РФ, депутаты Государственной Аумы, сенаторы Совета Федерации, руководители дипломатических миссий. Наши выпускники прошлых лет возглавляли правительства в зарубежных странах, работали министрами и депутатами парламентов. Существует традиция, когда каждые пять лет представители выпусков встречаются в Московском гуманитарном университете и вспоминают о своей студенческой жизни.

\section{ПРИМЕЧАНИЯ}

1 Бунт, которого не было (2017) [Электронный ресурс] // Новая газета. 24 октября. URL: https://www.novayagazeta.ru/articles/2017/10/24/74310-bunt-kotorogo-ne-bylo (дата обращения: 30.08.2019).

${ }^{2}$ Борис Ельцин: «Сегодня все вопросы должны быть прямые» [Электронный ресурс]// Ельцин-Центр. URL: https://yeltsin.ru/news/boris-elcin-segodnya-vse-voprosy-dolzhny-byt-pryamye/ (Аата обращения: 30.08.2019).

${ }^{3}$ Там же.

${ }^{4}$ Там же.

\section{СПИСОК АИТЕРАТУРЫ}

Благодаря комсомолу... (2018) : сборник выступлений / под общ. ред. И. М. Ильинского, А. В. Костиной. М. : ИКАР. 404 с.

Васильев, Ю. А., Мухамеджанов, М. М. (2011) История Центральной комсомольской школы при ЦК ВАКСМ. 1944-1969. М. : Московский гуманитарный университет. 66 с.

Ельцин, Б. Н. (1992) Исповедь на заданную тему. М. : Пик. 192 с.

Ильинский, И. М. (2009) Беседы об истории Московского гуманитарного университета. М. : ИзА-во Московского гуманитарного университета. 327 с.

Валерий Андреевич Ауков: концепции и исследования. Научные публикации (1966-2018) (2018) / сост. С. В. Ауков. М. : ИзА-во Московского гуманитарного университета. 165 с.

Наш страж и светоч: к 30-летию Высшей комсомольской школы - Института молодежи 1969-1999 (1999) / под общ. ред. И. М. Ильинского. М. : Социум. 368 с. 
Ручкин, Б. А. (2014) Хроника основных событий истории Московского гуманитарного университета за 70 лет // Научные труды Московского гуманитарного университета. № 11. С. 5-28.

Аата поступления: 03.09.2019 2.

\section{MOSGU IS 75: TIMES, EVENTS, PEOPLE \\ A. D. BORODAY \\ MOSCOW UNIVERSITY FOR THE HUMANITIES}

2019 is the year that Moscow University for the Humanities is celebrating a glorious jubilee 75 years since the day it was founded. It has come a long way in the field of higher education. Throughout its history, the university has had five different names: Central Komsomol School under the LYCLSU Central Committee (1944-1969) - Higher Komsomol School under the LYCLSU Central Committee (1969-1991) - Institute of Youth (1991-2000) - Moscow Humanitarian and Social Academy (2000-2003) - Moscow University for the Humanities (2003 - present).

What makes our university's history particularly interesting, significant and precious is its people. The university has always employed highly qualified professionals with vast experience in practical work who have become prominent scientists and established their scientific schools. Due to their knowledge and skills, the teachers have always been able to capture the students' interest. Most importantly, they have been generous and inspirational specialists, as well as unique personalities. The paper features a number of such specialists.

Keywords: Higher Komsomol School; Moscow University for the Humanities; higher education; history of the university

\section{REFERENCES}

Blagodaria komsomolu... (2018) : sbornik vystuplenii / ed. by I. M. Il'inskii, A. V. Kostina. Moscow, IKAR. 404 p. (In Russ.).

Vasil'ev, Iu. A. and Mukhamedzhanov, M. M. (2011) Istoriia Tsentral' noi komsomol' skoi shkoly pri TsK VLKSM. 1944-1969. Moscow, Moskovskii gumanitarnyi universitet. 66 p. (In Russ.).

El'tsin, B. N. (1992) Ispoved' nazadannuiu temu. Moscow, Pik. 192p. (In Russ.).

Il'inskii, I. M. (2009) Besedy ob istorii Moskovskogo gumanitarnogo universiteta. Moscow, Izd-vo Moskovskogo gumanitarnogo universiteta. 327 p. (In Russ.).

Valerii Andreevich Lukov: kontseptsiii i ssledovaniia. Nauchnye publikatsii (1966-2018) (2018)/ comp. by S. V. Lukov. Moscow, Izd-vo Moskovskogo gumanitarnogo universiteta. 165p. (In Russ.).

Nash strazh i svetoch: $k$ 30-letiiu Vysshei komsomol'skoi sbkoly - Instituta molodezhi 1969-1999 (1999) / ed. by I. M. Il'inskii. Moscow, Sotsium. 368p. (In Russ.).

Ruchkin, B. A. (2014) Khronika osnovnykh sobytii istorii Moskovskogo gumanitarnogo universitetaza 70 let. Nauchnye trudy Moskovskogo gumanitarnogo universiteta, no. 11, pp. 5-28.

Submissiondate: 03.09.2019.

Бородай Александр Амитриевич - доктор исторических наук, профессор, декан факультета рекламы, журналистики и дизайна, профессор кафедры теории рекламы и массовых коммуникаций Московского гуманитарного университета; заслуженный работник культуры Российской Федерации, почетный работник высшего профессионального образования Российской Федерации. Адрес: 111395, Россия, г. Москва, ул. Юности, д. 5, корп. 3. Тел.: +7 (499) 374-54-51. Эл. aApec: aboroday@mosgu.ru

BorodayAleksandrDmitrievich, Doctor of History, Professor, Dean, Faculty of Advertising, Journalism and Design, Professor, Department of Theory of Advertising and Mass Communications, Moscow University for the Humanities; Honoured Cultural Worker of Russia; Honoured Worker of Russian Higher Education. Postal address: 5, Yunosti St., Moscow, Russian Federation, 111395. Tel.: +7 (499) 374-54-51. E-mail: aboroday@mosgu.ru 